\title{
The Relationship of Halal-Logistics Value Creation on Firm Performance in Perlis
}

\author{
Hasrul Bin Hashom*, Nainatul Farzuha Binti Nor, Nor Izham Bin Subri, and
}

Mohd. Anas Zakwan Bin Sabri

Kolej Universiti Islam Perlis (KUIPs Lot 18 - 27 Rumah Kedai Dua Tingkat Taman, 02000 Kuala Perlis, Perlis, Malaysia

*Corresponding Author. Email: hasrul@kuips.edu.my

\begin{abstract}
Malaysia as one of leading country in halal industry shows tremendous achievement in global market by providing Sharia compliance products and services. Therefore, with almost 90\% populated by Malay Muslim, Perlis provide vast market value to product and service related to halal in term of food and beverage, agricultural and basic agricultural industry; not only cater the national need, but also regional and international market. The ability of the state to maintain in promoting halal destination will enhance their position as tourist destination and boost up the standard living for locals and state procurement. The research also to support the Sustainable Development Goals (SDG) No.12 : Responsible Consumption And Production. Therefore, the purpose of the research is to provide the finding in the implementation of Halal-Logistics Value Creation (HLVC) among Micro, Small and Medium Enterprise (MSMEs) in Perlis and the effectiveness of HLVC toward firm/ business performance.
\end{abstract}

Keywords: Halal, Logistics, Firm, Performance

\section{INTRODUCTION}

Perlis has the potential to grow as a business networking in Malaysia including creating halallogistics value creation. This is evidenced based on Perlis internal ability such as low cost of employment and business fees in Malaysia, provide exclusive income tax exemption of $100 \%$ on statutory income for 5 years (industrial activity) in pioneer status, including up to $100 \%$ share hold of the equity in all investment in new projects for foreign investors. This effort is further strengthened by the cost of land and low rental provide vast opportunity to investors to penetrate Perlis business landscape. Located within the Growth Triangle of Indonesia-Malaysia-Thailand, the English medium is widely spoken and Perlis can be considered as a meeting point between the tourism sector that connects the tourist attractions in Langkawi and Thailand. Problem rising based on figure worth mentioning of 383,000 tourists through Padang Besar border crossing in 2009 to entered Malaysia (a figure that is rise year after year), which the majority of them sailed right through Perlis without giving it a second thought. Various matters were considered and cooperation between the state and federal governments has sparked ideas towards more robust long -term planning. The Northern

Corridor Implementation Authority (NCIA) are working hard looking at ways of developing the Malaysia Thailand crossing points to improve bilateral trade. The dry port at Padang Besar, which is currently undergoing facility upgrades, is part of this effort to extend Perlis' chain of operation, supply, and logistics, as well as to improve the state's overall economic landscape. On this occasion, Malaysia has and continues to make efforts in championing the halal hub sector. Therefore, the uniqueness of the business and the rebranding of Perlis as a halal logistics provider for goods and services is seen to have significant potential to lift the economy of Perlis.

In order to protect the quality or threshold (halal) in the supply chain, halal logistics services are vital to ensure continuity of acts. Therefore, most of the studies on halal logistics was directly to focus on perspective of policy makers and service providers [1]. This was related to the emerging of new customer interest on halal value chain, regarding of conveniences, safety and welfare across the supply chain [2] including the application of tracing system to determine the origin of the product; to trace the source of contamination [3]. 
Based on the issue arise, the needs of an integrated halal logistics management system to be implement is crucial. Moreover, the halal logistics segment shows increasing on market preferable, but the studies was still limited especially in academic research [4]. Even previous studies provide mixed empirical findings regarding the halal logistics management system toward firm performance, but it is limited to logistics industry alone without tap into other industry especially micro, small and medium nature industry especially in Perlis. Therefore, the research intent to provide empirical data outcomes to study on halal-logistics value creation on firm performance in Perlis states at northern Malaysia. The study also motivated by international agenda towards on Sustainable Development Goals (SDG) clause No.12: Responsible Consumption And Production, whereas halal and wholesomeness (tayyab) become crucial since it is a symbol of hygiene and food safety related to ingredients, equipment and utensil, packing, storage, processing, transport and waste management to ensure the quality of production and the safety for human consumption [5].

It is proven that halal market scope is very promising for halal manufacturers to market their products internationally. Storage, distribution, delivery or transportation is part of the halal logistics mechanism where of "from farm to fork" involves the entire supply chain network right from the source to final consumption [6]. Halal logistics, as defined by [7], does not vary significantly from conventional methods such as controlling the production, transport, storage and handling of commodity components, products, semi-finished or finished food and nonfood objects in the supply chain network with Shariah values being followed. Essentially, the field of halal logistics in Malaysia is still a newborn, so that matters such as expertise, know-how and publications are quite limited [8]. Halal logistics relates to the process for procurement handling, storage, transition and control of material component, livestock, a partially completed or full inventory of consumable and non-consumable products and that those procedures must comply with 'Shariah.' [7] Product/service with halal branding, in particular food; referred to in [9] Tieman (2011), could be suspected if it came into direct contact with nonHalal during processing, storage, transport and handling.

To date, some previous research has succeeded in identifying the indispensable problems in halal logistics, mainly in three predominant areas; transport and movement, storage and warehousing, and terminal operations and processing [10]. To fulfil halal principles, these areas should be separated by way of nonhalal (haram) parts or products physically even interior the container, shelves, and cold- rooms or packaging. If there is a breach or contamination, the procedure of undergo an additional cleaning or web page need to be applied through using clay and water $[11,12]$ pioneering the study to conceptualize halal value creation as service innovation on logistics service providers, a new way of thinking about organizational management or a holistic way of delivering a range of services for different customer needs, minimizing costs and optimizing profit (economy), product / service (quality), people (society) and the planet (environment) benefits is already under way. Hence, this research determines to test halal value-creation construct consisting of product, profit, people and planet, since the capabilities of the halal logistics service are linked to how efficiently input resources are converted into the production of halal value for customers [13].

\section{METHODS}

The study was conducted through survey and the data of this study was gathered by questionnaires distribution involving micro, small and medium businesses in Perlis. The selection of samples was among registered businesses under Perlis's Economy Planning Division with total population of 1781 firms/entrepreneurs. Since the population of the study are micro, small and medium firms/business in Perlis, the micro business respondents considered as not bound by physical conditions such as preparation of business forecasts, annual financial reports, and several other. Recommendation by [5] was implemented to determine the study sample, where the probability sampling method was used because the study population had the same opportunity to be selected as the respondent other than the sample needs to meet the wider and broader goals [8]. Researchers used simple random sampling techniques [7] based on population numbers that are considered to have similar characteristics and to avoid bias in sample select. Therefore, sample selection will perform randomly using Microsof Excel 2016 software. Total of 300 questionnaires were disseminated to businesses in Perlis via email, WhatsApp phone number and walk in method to the nearest respondent's outlet. The questionnaires were addressed to the owner or managers of the business. The online method is the most frequent use since the restriction to move was impose by government starting March 18, 2020 until present day. Even Perlis already in condition of Recovery Movement Control Order (RMCO), but the respondent still subject to authority instruction on the number of total attendance especially management level to work place. Therefore, in parallel with work from home policy, the researcher using information 
Table 1. Research Demography

\begin{tabular}{|c|c|c|}
\hline Characteristic & Frequency & Percentage \\
\hline \multicolumn{3}{|l|}{ Ownership Status } \\
\hline Bumiputera & 126 & 94.7 \\
\hline Non Bumiputera & 7 & 5.3 \\
\hline \multicolumn{3}{|l|}{ Number Of Employee } \\
\hline Less Than 5 & 57 & 42.9 \\
\hline Between $5-75$ & 76 & 57.1 \\
\hline More Than 75 & 0 & 0 \\
\hline \multicolumn{3}{|l|}{ Sales Turnover } \\
\hline Less Than 300,00 & 118 & 88.7 \\
\hline Between 300,000 To 15 Million & 15 & 11.3 \\
\hline More Than 15 Million & 0 & 0 \\
\hline \multicolumn{3}{|l|}{ Business Sector } \\
\hline Manufacture (Chemical Production) & 3 & 2.3 \\
\hline Manufacture(Food And Beverage) & 40 & 30.1 \\
\hline Services(Restaurant) & 11 & 8.3 \\
\hline Services(Transportation) & 5 & 3.8 \\
\hline Services(Warehouse) & 1 & 0.8 \\
\hline Production(Agricultural) & 3 & 2.3 \\
\hline Production(Agro-Based) & 56 & 42.1 \\
\hline Others / Retail & 14 & 10.5 \\
\hline \multicolumn{3}{|l|}{ Years Started } \\
\hline Before 2000 & 54 & 40.6 \\
\hline 2001-2005 & 47 & 35.3 \\
\hline $2006-2010$ & 13 & 9.88 .3 \\
\hline 2011-2015 & 11 & 6.0 \\
\hline 2016-2020 & 8 & \\
\hline \multicolumn{3}{|l|}{ Business Range } \\
\hline Local & 133 & 100 \\
\hline Regional & 0 & 0 \\
\hline International & 0 & 0 \\
\hline
\end{tabular}

communication technology to access business owner or firm's top management to get the respond. Only 147 questionnaires able to collect from the respective respondent and the primary data were collected from structured questionnaires distribute as mention at above.

\section{RESULTS}

In order to classify the business types, it can be said that the survey covers industries including food producer, agriculture and basic agriculture, groceries store, bakery, restaurants and small-scale food and beverage manufacturing, and others. The demography characteristics of sample respondents as below;

The data gather from the survey found that more than $90 \%$ respondents were in bumiputera category. This includes the local Siamese ethnic with reside along the Padang Besar and Wang Kelian located near to Malaysia-Thailand border. The number of employees and sales turnover were to determine the definition of each criterion whether it is micro, small or medium enterprise. This criterion categorizes 
Table 2. Crobanch Alpha Value

\begin{tabular}{|l|c|c|}
\hline Variable & No. Of items & Crobanch alpha \\
\hline Firm Performance & 4 & 0.910 \\
\hline Halal Logistic Value Creation & 16 & 0.886 \\
\hline
\end{tabular}

firm/business with employees less than 5 workers and sale turn over less than RM300k for micro enterprise, company with more than 5 to 75 and yearly turnover between RM300k to RM15 million consider as small enterprise and so on (smecorp.gov.my). Based on the data collected, $88.7 \%$ respondents can be assumed as micro entrepreneurs/enterprise while only $11.3 \%$ categorize as small firm and no firm in medium category involve or respond to the questionnaire. The data also shows that, most of the respondents was in agro-based industry production with consist of $42.1 \%$, food and beverage manufacture industry of $30.1 \%$, retails $10.5 \%$, restaurant service of $8.3 \%$ and few other industries with small return on feedback. Most of the firms starting the business more than 20 years which comprise of $85.7 \%$ while only $6 \%$ started their business in previous 5 years. All respondent in this study confirm that their business range only limited to local market. The analysis only considered data extraction from acceptance questionnaire with gone through the cleaning process.

From the total of returned questionnaires, only 133 are usable after data cleaning process. It is proven that 14 questionnaires were rejected because the respondent not fill the answers completely and 1 questionnaire was sent twice by the same company. The questionnaire on this survey consisted of 27 questions in total which are divided into 3 sections which are section one is Firm Demography; section two is Firm Performance and section three is Halal-Logistics Value Creation. Section one consists of 7 questions, whereas question 1 until 7 was used to obtain the information of the businesses characteristics. The remaining 2 sections include 4 questions which were designed to investigate the firm performances in previous three years and 16 questions were on halal-logistics value creation instrument such as packaging, warehousing, transportation and management systems. The variables has been using the Likert's scale which are inclusive of $1=$ Strongly Disagree, 2 = Disagree, $3=$ Neutral, $4=$ Agree and $5=$ Strongly Agree. The reliability of all instrument as below stressed, a range of between 25 and 100 subjects was sufficient to indicate the reliability and validity of the instrument. The number of questionnaires was distributed to respondents directly involved micro, small and medium firms in Perlis [11]. To Indicate the internal consistency, [7] suggested that the most common measurement tool is the used of Cronbach Alpha coefficient to measure reliability as it is also expected to provide good guidance. [7] described Crobanch Alpha statistic can be accounted as a value range from 0 to 1 where values less than 0.6 were considered weak or poor while 0.7 values were considered acceptable and greater than 0.8 .

Crobanch Alpha is to measure the reliability of the instruments in this research and analysis performed on all variables associated with this study provide good guidance in determining the level of reliability [7]. Therefore, reliability analysis run over the items of all variables resulted as shows in Table 1.1. The reliability of the items could be accepted as resulted of Cronbach's Alpha ranging from 0.886 for halallogistics value creation to 0.910 for firm performance. Based on the reliability analysis, the outcomes of the study as below.

Items for firm performance instruments consist of improvement in company profit (question number 8), return on investment (question number 9), return on

Table 3. Firm Performance Analysis

\begin{tabular}{|l|l|l|l|l|}
\hline \multicolumn{1}{|c|}{ Items } & Mean & \multicolumn{1}{c|}{$\begin{array}{c}\text { Std. } \\
\text { Deviation }\end{array}$} & Max. & Min. \\
\hline The company showed improvement in its profit & 3.5188 & .86691 & 5.00 & 2.00 \\
\hline $\begin{array}{l}\text { The company showed improvement in the average return on } \\
\text { investment (ROI) }\end{array}$ & 3.6391 & .86461 & 5.00 & 2.00 \\
\hline $\begin{array}{l}\text { The company showed improvement in the } \\
\text { average return on asset (ROA) }\end{array}$ & 3.4286 & 1.03196 & 5.00 & 2.00 \\
\hline The company employment growth rate & 3.0902 & .85687 & 5.00 & 2.00 \\
\hline
\end{tabular}


asset (question no.10) and employment rate (question number 11). employment growth mean at only 3.0902. This also reflect the improvement of business return on asset (ROA) with mean score of 3.43. The result is related to

Table 4. Halal-Logistics Value Creation Items of Each Construct

\begin{tabular}{|c|c|c|}
\hline Question & Items & Constructs \\
\hline No. 11 & $\begin{array}{l}\text { Our company dedicate to ensure our/outsource products packaging does not contain } \\
\text { any non-halal parts of products or animals that is not slaughtered according to Shariah } \\
\text { methods or contain alcohol substance }\end{array}$ & \multirow[t]{2}{*}{ Packaging } \\
\hline No. 15 & $\begin{array}{l}\text { Our company believe by maintains hygienic working environment will enhance } \\
\text { profitability }\end{array}$ & \\
\hline No. 19 & $\begin{array}{l}\text { Our employee/outsource understand the Islamic requirements in halal product/service in } \\
\text { packaging }\end{array}$ & \\
\hline No. 23 & $\begin{array}{l}\text { The company committed on safe and not harmful packaging process toward } \\
\text { environment }\end{array}$ & \\
\hline No. 12 & $\begin{array}{l}\text { Our company committed to ensure the product/service store in place that hygiene, } \\
\text { quality and safe }\end{array}$ & \multirow{4}{*}{ Warehousing } \\
\hline No. 16 & $\begin{array}{l}\text { Our company believe by ensures safe, secure and clean vicinity is important for } \\
\text { warehouse }\end{array}$ & \\
\hline No. 20 & $\begin{array}{l}\text { Our employee/outsource understand the procedures of handling halal product/service } \\
\text { for storage / }\end{array}$ & \\
\hline No. 24 & $\begin{array}{l}\text { The company believe that segregation and strict between halal and non-halal products } \\
\text { during halal logistics services will help improve the transportation cost and energy }\end{array}$ & \\
\hline No. 13 & $\begin{array}{l}\text { Our company committed to ensure all items stored in a transportation should the halal } \\
\text { products only }\end{array}$ & \multirow{4}{*}{ Transportation } \\
\hline No. 17 & $\begin{array}{l}\text { Our company believe by emphasizes on strategic plan location will save the cost and } \\
\text { energy }\end{array}$ & \\
\hline No. 21 & $\begin{array}{l}\text { Our employee/outsource are competent and skillful in carrying out the responsible in } \\
\text { transportation }\end{array}$ & \\
\hline No. 25 & $\begin{array}{l}\text { The company committed on warehouse environment area are clean and follow sanitation } \\
\text { schedule to avoid air, water and noise pollution and contamination }\end{array}$ & \\
\hline No. 14 & $\begin{array}{l}\text { Our company will ensure Shariah ritual cleansing will be done if the warehouse and } \\
\text { transportation is found contaminated with material categorized as najs mughallazah (the } \\
\text { most filthy excrement) }\end{array}$ & \multirow{4}{*}{$\begin{array}{c}\text { System } \\
\text { Management }\end{array}$} \\
\hline No. 18 & Our company believe company or logistics player should apply traceability system & \\
\hline No. 22 & $\begin{array}{l}\text { Our employee/outsource provide adequate training given in handling halal } \\
\text { product/service }\end{array}$ & \\
\hline No. 26 & $\begin{array}{l}\text { The company alert on advance information system help to improve the quality of our } \\
\text { planet }\end{array}$ & \\
\hline
\end{tabular}

As stated in Table 1.2, the overall positive means score for the four question's items ranging from 3.0902 to 3.6391 has been decided and agreed by the respondents that the company showed improvement in the average return on investment (ROI) and improvement in business profit, which each mean scores of 3.64 and 3.52 , rather than the ability in business firm performance for more than three years in row based on self-report. The self-report method was also implement previous researchers to obtain feedback on the performance of these SME firms. The subjective or self-report financial measures were proven to be reliable [9], and it can fully explain the actual performance of a given firm [13] . 
Table 5. Correlation Analysis Between Variables

\begin{tabular}{|l|l|l|l|l|l|}
\hline & Firm_Performance & Packaging & Warehouse & Transportation & $\begin{array}{c}\text { Management } \\
\text { System }\end{array}$ \\
\hline Firm_Performance & 1 & & & & \\
\hline Packaging & $.299^{\star \star}$ & 1 & & & \\
\hline Warehouse & $.362^{\star \star}$ & $.756^{\star \star}$ & 1 & & \\
\hline Transportation & $.321^{\star \star}$ & $.625^{\star \star}$ & $.712^{\star \star}$ & 1 & \\
\hline $\begin{array}{l}\text { Management } \\
\text { System }\end{array}$ & $.340^{\star \star}$ & $.541^{\star \star}$ & $.689^{\star \star}$ & $.915^{\star \star}$ & 1 \\
\hline
\end{tabular}

**. Correlation is significant at the 0.01 level (2-tailed

In the other hand, halal awareness among the industry players especially among the micro, small and medium firms is still inconsistent between subindustries even the demography of Malaysia consist of $60 \%$ Muslims population [15], which shows high sensitivity in halal issues and processes including the logistics of the goods and services.

To analyze Halal-Logistics Value Creation towards firm performance, researcher have categorized items based on constructs consist of packaging, warehousing, transportation and management system as shows in Table 4;

To examine the influence of Halal-Logistics Value Creation constructs on firm performance, this analysis will explain the multivariate relationship between the variables involved. Before regression analysis perform, Pearson Coefficient Correlation analysis was performed to determine the direction and strength of the relationship between the dependent variable (firm performance) with each construct in the independent variable (Halal-Logistics Value Creation), The result

of the analysis found that all variables were significantly positive correlated with each other with a confidence level of more than $50 \%$ for halal-logistics value creation except for firm performance as shown in Table 4.3. It is found that the relationship between firm performance with each construct is positively small correlated where the value of $\mathbf{r}$ is less than 0.5 .
Firm performance has a significant relationship and is positively correlated with packaging constructs ( $\mathrm{r}$ $=0.141, \mathrm{p}<0.01)$, warehousing constructs $(\mathrm{r}=0.197$, $\mathrm{p}<0.01)$. Transportation constructs $(\mathrm{r}=0.185, \mathrm{p}<0.01)$ and management systems constructs $(\mathrm{r}=0.16 .1$, $\mathrm{p}<0.01)$. Correlation analysis also proved the interrelationship of each independent variable are free of the multicollinearity effect when all significant $r$ values did not exceed the value of 0.70 [9].

Next, the regression analysis was performing to estimate the relationship between dependent variable (firm performances) and the independent variable (Halal-Logistics Value Creation). Analysis shows, the regression scores is $\mathrm{R}=0.387$ and $\mathrm{R} 2=0.149$. These results indicate that the constructs of the HalalLogistics Value Creation variable studied can explain as $38.7 \%$ of the variation that occurs in firm performance. $\mathrm{R} 2$ is significant with a value of $\mathrm{F}=5.622$ and a significant level value at $\mathrm{p}=0.000$ as described in Table 1.5. This indicate the variance between the mean of dependent and independent constructs is significantly different while small score of R2 represent huge differences between the variables values. Refer to Table 1.6, the results of the study show that all HalalLogistics Value Creation constructs have a low significant relationship towards firm performance. It was found that packaging construct has a significant positive relationship on firm performance $(\beta=.136)$ with a value of $t=.520$ and a value of $p=0.604$ indicating that packaging construct low significant relationship with firm performance at $\mathrm{p}<0.05$. These

Table 6. Regression Analysis Between Halal-Logistics Value Creation and Firm Performance

\begin{tabular}{|c|c|c|c|c|}
\hline$R$ & R Square & Adjusted R Square & $F$ & Sig, F \\
\hline $.387 a$ & .149 & .123 & 5.622 & .000 \\
\hline
\end{tabular}


findings show that packaging is a halal-logistics value creation instrument that have small contribution to firm performance. In addition, the analysis showed that the transportation constructs had a low significant with negative relationship towards firm performance $(\beta=$ .199 ), which a value of $t=-.452$ while value of $p=0.652$; indicate that the transportation construct had lowest significant relationship with firm performance at $\mathrm{p}=.652$. These findings show that transportation is a halal-logistics value creation instrument that contribute the lowest improvement on firm performance. On contrary, the finding of the analysis of warehousing construct had the highest significant positive relationship on firm performance $(\beta=.472)$ with a value of $t=1.449$ and a value of $p=.150$. This indicate that the warehousing construct had a slightly significant positive relationship with firm performance at $\mathrm{p}=.150$. These findings show that warehousing is a halallogistics value creation instrument that can improve firm performance. Finally, it was found that the management system construct also has a significant positive relationship on firm performance $(\beta=.431)$ with a value of $\mathrm{t}=1.199$ and a value of $\mathrm{p}=.233$ indicating that the construct of management system also has slightly significant relationship with firm performance at $\mathrm{p}<0.05$. These findings show that the management system is a halal-logistics value creation instrument that can improve firm performance.

\section{DISCUSSION}

The purpose of this study was to gather the relationship between halal-logistics value creation and firm performance by the micro, small and medium enterprises in Perlis. Through information gathered from this study, it was discovered that the moderate relationship is exists between the halal-logistics value creation that increase the firm performance in Micro, Small and Medium Enterprises (MSMEs). Generally, the survey reveals that Perlis enterprises that implement halal-logistics value creation which consist of packaging, warehousing, transportation and management systems is still low, thus it leads to the low improvement of firm performance.

Secondly, most of the MSMEs business enterprises support the idea of using halal-packaging as to maintains hygienic working environment will enhance profitability and avoid using non-halal parts of products or animals that is not slaughtered according to Sharia' methods or contain alcohol substance. then proceed into computerized record keeping system. But in practical, with $90 \%$ business respondents are Muslim and already run the business for generation felt that halalpackaging have small impact towards firm performance.

Third, in terms of the needs emphasis on warehouse/storage facilities, respondent committed in providing place that hygiene, quality and safe. They understand the need of a procedures of handling halal product/service for storage and the strict segregation between halal and non-halal products during halal logistics. This issues can be considered as national concern since the warehouse /storage contamination between halal and non halal product will also affect the firm performance and branding. Therefore, respondents also concerned over management system in maintaining the process to not contaminating with nonhalal substance and activities. Respondents believe ensure Sharia' ritual cleansing will be done if the warehouse and transportation is found contaminated with material categorized as najs mughallazah, logistics player should apply traceability system, adequate training given in handling halal product/service is needed and advance information system help to improve the quality of environment.

Finally, with regards to halal-transportation, which concerned on a matter of all items stored in a transportation should the halal products only, believe strategic plan location will save the cost and energy and

Table 7. Regression Analysis Between Halal-Logistics Value Creation Constructs and Firm Performance

\begin{tabular}{|c|c|c|c|c|c|}
\hline \multirow[t]{2}{*}{ Constructs } & \multicolumn{2}{|c|}{ Unstandardized Coefficients } & \multirow{2}{*}{$\begin{array}{c}\text { Standardized Coefficients } \\
\text { Beta }\end{array}$} & \multirow[t]{2}{*}{$\mathrm{t}$} & \multirow[t]{2}{*}{ Sig } \\
\hline & B & Std. Error & & & \\
\hline (Constant) & -.162 & .847 & & -.191 & .849 \\
\hline Packaging & .136 & .262 & .067 & .520 & .604 \\
\hline Warehouse & .472 & .326 & .210 & 1.449 & .150 \\
\hline Transportation & -.199 & .440 & -.099 & -.452 & .652 \\
\hline Management System & .431 & .359 & .250 & 1.199 & .233 \\
\hline
\end{tabular}


ensuring the competent and skillful staff in carrying out the responsible in transportation to maintain the halalness is safeguarding at all time, almost all respondents shows they have lowest awareness on halal-transportation issues. This is since, either entrepreneurs or consumer will affect by transportation cost and other standing cost such as warehouse/storage services or management. Logically, micro and small businesses will only focus on local market rather than regional and international. Therefore, even if outsource transportation involve in supply chain, it is believed will not affected the firm performance.

\section{CONCLUSION}

As a conclusion, the halal-logistics implementation will create value creation on business and lead into consistency and continuity in achieving high performance of business profit. But in the case of Perlis demography with small scales of existing market and fewer tourist inflow, the awareness of the important of halal value creation especially in logistics services to cater international and regional market is still at very low. Thus firms need to be able to create halal circle between all stakeholders and thrust over their respective customers and clients in long term. With extreme changes on implementation of halal value creation will help firms expanding in orderly, efficient and accountable manner. This effort not only improve their firm performance, but also moving globally to champion in Sustainable Development Goals (SDG) No.12: Responsible Consumption And Production by providing not only safe and hygiene for products but also in halal-logistics value creation.

\section{REFERENCES}

[1] Ali, N. M., Rahman, M. M., Ahmad, R., \& Mahdzan, N. S. A. (2015). Necessity of Effective and Efficient Business Model for Development of Social-entrepreneurship lands in Malaysia of Socialentrepreneurship lands in Malaysia. In Muktamar Social-entrepreneurship Iqlimi II 2015 (pp. 351-364). Universiti Sains Islam Malaysia (USIM). $\quad$ Retrieved from http://www.researchgate.net/publication/28 0088128_Necessity_of_effective_and_efficient_ business_model_for_development_of_Socialentrepreneurship_lands_in_Malaysia

[2] Ali, R., Ismail, S., \& Saed, A. M. (2015). Creating Young Entrepreneurs in Malaysia through Socialentrepreneurship Structuration Framework. Australian Journal of Basic and Applied Sciences, 9(28), 225-229.

[3] Kautonen, T., Tornikoski, E. T., \& Kibler, E. (2011). Entrepreneurial Intentions in The Third
Age: The Impact Of Perceived Age Norms. Small Business Economics, 37(2), 219234. http://doi.org/10.1007/s11187-009-9238-y

[4] Sumra, S. H., Safarish, H., Suhail, S., \& Ahmad, S. T. (2011). Factors Responsible for Low Inclination towards Entrepreneurship in the Public Sector Institutions of Pakistan. Journal

[5] Othman, B., Md. S., Bahron, A., \& Md. Nawi, N. H. (2019). The Influence of Halal Practices On Organizational Performance Among Food Industries (SMEs) In Malaysia. Halal Journal, 3, 1394- 4428 .

[6] Hunt, S.D., "A General Theory of Business Marketing: R-A theory, Alderson, the ISBM Framework and the IMP Theoretical Structure," Industrial Marketing Management, Vol. 41, 2013, pp 283-293

[7] Tieman, M. (2013), "Establishing the principles in halal logistics", Journal of Emerging Economies and Islamic Research, Vol. 1 No. 1, pp. 1-13.

[8] Harun, F. M., Possumah, B. T., Shafiai, H. B. M., \& Noor, A. H. M. (2016). Issues and Economic Role of Social-entrepreneurship in Higher Education Institution: Malaysian Experience. Al-Iqtishad: Journal of Islamic Economics, $\quad 8(1)$. http://doi.org/10.15408/aiq.v8i1.2514

[9] Irwan Ibrahim, Norina Ahmad Jamil \& Izhal Abdul Halin (2018); “Green Enterprise Resource Planning and Green Logistics Performance", The SIJ Transactions on Industrial, Financial \& Business Management (IFBM), Vol. 6, No. 1

[10] Fischer, J. (2012), "Branding halal: A photographic essay on global Muslim markets", Anthropology Today, Vol. 28 No. 4, pp. 18-21.

[11] Botoseneanu, A., Alexander, J. A., \& BanaszakHoll, J. (2011). To Test or Not to Test? The Role of Attitudes, Knowledge, and Religious Involvement among U.S. Adults on Intent-toObtain Adult GeneticTesting. Health Education \& Behavior, 38(6), 617-628. http://doi.org/10.1177/1090198110389711

[12] Karia, N., and M. H. A. H. Asaari. (2015). "Enhancing Halal Sustainability: Resources and Capability of Operations in Third-party Logistics (3PL)." WSEAS Advances in Business and Economic Development 2: 206-211.

[13] Karia, N., and M. H. A. H. Asaari, (2016)."Transforming green logistics practice into benefits: a case of third-party logistics (3PLs)" Proceedings of the 2016 International Conference on Industrial Engineering and 
Operations Management 978-1-4673-7762$1 / 16$

[14] Mahamood, S. M. (2007). Pembentukan Dana Wakaf Menurut Perspektif Syariah dan UndangUndang Serta Aplikasinya Di Malaysia. Jurnal Syariah, 15(2), 61-83. Retrieved from http://umijms.um.edu.my/filebank

[15] Department of Statistics Malaysia, (2014). Retrieved from http://www.statistics.gov.my/portal/index.php?o ption=com_content $\&$ view $=$ article $\&$ id $=2$
\%3Amonthly-principal-statistics-of-labour-force malaysia\&catid=92: monthly-principal statisticsof-labour-force-

[16] Keat, O. Y., Selvarajah, C., \& Meyer, D. (2011). Inclination towards Entrepreneurship among University Students: An Empirical Study of Malaysian University Students. International Journal of Business and Social Science, 2(4), 206-22 